Review

\title{
Transmission of SARS-CoV-2 Indoor and Outdoor Environments
}

\author{
Xueli $X u^{1,2,+}$, Jing Zhang ${ }^{2,+}$, Liting Zhu ${ }^{1}$ and Qiansheng Huang ${ }^{1, *}$ \\ 1 Key Lab of Urban Environment and Health, Institute of Urban Environment, Chinese Academy of Sciences, \\ Xiamen 361021, China; xlxu@iue.ac.cn (X.X.); ltzhu@iue.ac.cn (L.Z.) \\ 2 College of Resources and Environment, University of Chinese Academy of Sciences, Beijing 100049, China; \\ gjx20170@gmail.com \\ * Correspondence: qshuang@iue.ac.cn; Tel.: +86 -592-619-0542 \\ $+\quad$ Xueli Xu and Jing Zhang contributed equally to this work.
}

check for updates

Citation: Xu, X.; Zhang, J.; Zhu, L.;

Huang, Q. Transmission of

SARS-CoV-2 Indoor and Outdoor

Environments. Atmosphere 2021, 12,

1640. https://doi.org/10.3390/

atmos 12121640

Academic Editors: Yu Feng,

Thierry Marchal and Xiaole Chen

Received: 28 October 2021

Accepted: 27 November 2021

Published: 8 December 2021

Publisher's Note: MDPI stays neutral with regard to jurisdictional claims in published maps and institutional affiliations.

Copyright: (c) 2021 by the authors. Licensee MDPI, Basel, Switzerland. This article is an open access article distributed under the terms and conditions of the Creative Commons Attribution (CC BY) license (https:/ / creativecommons.org/licenses/by/ $4.0 /)$.

\begin{abstract}
Since the outbreak in late December 2019, the coronavirus disease 2019 (COVID-19) pandemic has spread across the globe, causing great damage to human life and property. A lot of researchers around the world have devoted themselves to the study of its origin, pathogenic mechanism, and transmission route, and this article gives a summary. First, both humans and animals can act as the host of coronavirus. In indoor environments, the virus may exist in aerosols, droplets, saliva, etc., from the nose and mouth connected to the respiratory system, as well as feces, urine, etc., from the digestive and urinary systems. In addition, other substances, such as breast milk, eye feces, and blood, released from the host can carry viruses. The virus transmitted indoors is affected by indoor machinery, natural forces, and human activities, and spreads in different distances. Second, the virus spreads outdoors through three kinds of media: solid, liquid, and gas, and is affected by their survival time, the temperature, and humidity in the environment.
\end{abstract}

Keywords: SARS-CoV-2; transmission; indoor; existence form; survival time; environmental factors

\section{Introduction}

COVID-19, the third-highest contagious respiratory disease, after severe acute respiratory syndrome coronavirus (SARS-CoV) and Middle East respiratory syndrome coronavirus (MERS$\mathrm{CoV})$, is the disease caused by a new coronavirus known as severe acute respiratory syndrome coronavirus 2 (SARS-CoV-2). The World Health Organization (WHO) first learned of this new virus on 31 December 2019, following a report of a cluster of cases of "viral pneumonia" in Wuhan, People's Republic of China (https:/ / www.who.int/emergencies/diseases/novelcoronavirus-2019/question-and-answers-hub/q-a-detail/coronavirus-disease-covid-19, accessed on 25 November 2021). Compared with SARS-CoV and MERS-CoV, which belong to the same genera, SARS-CoV-2 has a faster transmission speed and stronger mutation ability [1]. The real lethality of COVID-19 may range from $0.2 \%$ to $16.2 \%$ in different continents and geographic areas, while the mortality rates of SARS-CoV and MERS-CoV are $10 \%$ and $35.6 \%$, respectively $[1,2]$.

Human-to-human transmission was first reported on 22 January 2020 [3]. WHO declared that the virus can spread from an infected person's mouth or nose in large droplets and small aerosols when they cough, sneeze, speak, sing, or breathe heavily (https:/ / www. who.int/emergencies/diseases/novel-coronavirus-2019/question-and-answers-hub, accessed on 25 November 2021), and other people become infected under the conditions of direct or close contact (less than $1 \mathrm{~m}$ apart) with an infected person, particularly in indoor, crowded, and inadequately ventilated spaces [2]. Numerous researchers around the world have devoted themselves to the study of its origin, pathogenic mechanism, transmission route, etc., which has greatly promoted the treatment of COVID-19. Most of the evidence leans toward that the virus can be transmitted by direct human contact and indirect airborne transmission, such as aerosols and droplets, but there are different opinions, that 
SARS-CoV-2 cannot be transmitted through air transmission [4]. On the basis of reading relevant literatures and materials, in this paper, we summarize the possible transmission methods of SARS-CoV-2 in the indoor and outdoor environments and their influencing factors. We also sum up the form and time of virus presence in different environments.

\section{The Transmission Routes of the Virus}

\subsection{Transmission Routes of the Virus in the Indoor Environment}

With the rapid development of global urbanization, a variety of commercial buildings, residential buildings, and public buildings are developing rapidly, in which most people spend more than $90 \%$ of their daily lives [2]. Human-built places are huge virus containers which include a variety of fomites carrying the virus. The virus on them or shedding from them is exchanged or transferred by the airflow caused by nature, men, machines, and equipment. The increasing occupant density facilitates the accrual of human-associated virus through the close interactions between human beings and things around them [2] in the indoor environment. As a result, the indoor environment can be the medium for infection and is worthy of attention and research.

\subsubsection{Virus Shedding from Hosts}

Both human beings and animals can be the hosts of the virus [1,5-8]. The virus is likely to leave the hosts and enter the environment during the exchange of solid, liquid, and gas between the interaction of hosts and the external environment [2]. The samples from hosts are likely to carry the virus. The properties of SARS-CoV and MERS-CoV are similar to [9] SARS-CoV-2, and they all belong to the genera of Betacoronavirus [1], thus they are all included in this discourse.

With the accumulation of clinical data, it is amazing to find that SARS-CoV-2 can extend to many human organs, including the brain, eyes, nose, lungs, heart and blood vessels, liver, kidneys, and intestines, and causes deep damage to the whole body [10]. Figure 1 presents the existence and secretion of virus in a human body.

Considering the convenience and reliability of the samples, most of the articles have been published regarding testing samples from the respiratory system (nasal swabs, oropharyngeal swab, saliva) $[9,11]$, the circulation of the blood system (blood) [12], and digestive and urinary system (feces, urine) [13-15] for diagnosis of infection [16-21]. Early in the outbreak (February 2020), the researchers tested the urine samples of nine patients who were diagnosed in the Third Affiliated Hospital of Sun Yat-sen University. The average age of the nine patients was $38.9 \pm 11.8$ years, and there were five females and four males. One of the nine confirmed patients tested positive. This was the first time that SARS-CoV-2 RNA was identified in the urine of an infected patient [15]. In addition, positive tests were found on blood, anal, and throat swabs from the nine patients [15]. On 20 January 2020, the U.S. Centers for Disease Control confirmed that a 35-year-old patient's nasopharyngeal and oropharyngeal swabs tested positive for SARS-CoV-2 by real-time reverse-transcriptase polymerase-chain-reaction assay [19]. There were 18 patients who were first confirmed with COVID-19 in Singapore between 23 January and 3 February 2020 [21]. The median age of the 18 hospitalized patients is 47 years (nine women, nine men). In the first 2 weeks, specimens (blood, stool, and urine samples; nasopharyngeal swabs) were collected at multiple time points and tested by RT-PCR for the presence of SARS-CoV-2. Viruses were found in stool (4/8) and in the whole blood (1/12), but not in urine [21]. The presence of SARS-CoV and MERS-CoV RNA in lower respiratory tract specimens, nasopharyngeal aspirates, feces/stool, upper respiratory tract specimens, serum/blood, and urine have been detected by many researchers $[17,22,23]$. These show that SARS-CoV-2 has similar spatial distribution in the patient's body to SARS-CoV and MERS-CoV, and it is speculated that they have similar attack sites on the hosts. Therefore, researchers can learn from the previous research, defense, and treatment measures of SARS-CoV and MERS-CoV. All these references support that the respiratory system, the urinary system, digestive system, and blood circulation system can be invaded by SARS-CoV-2. 


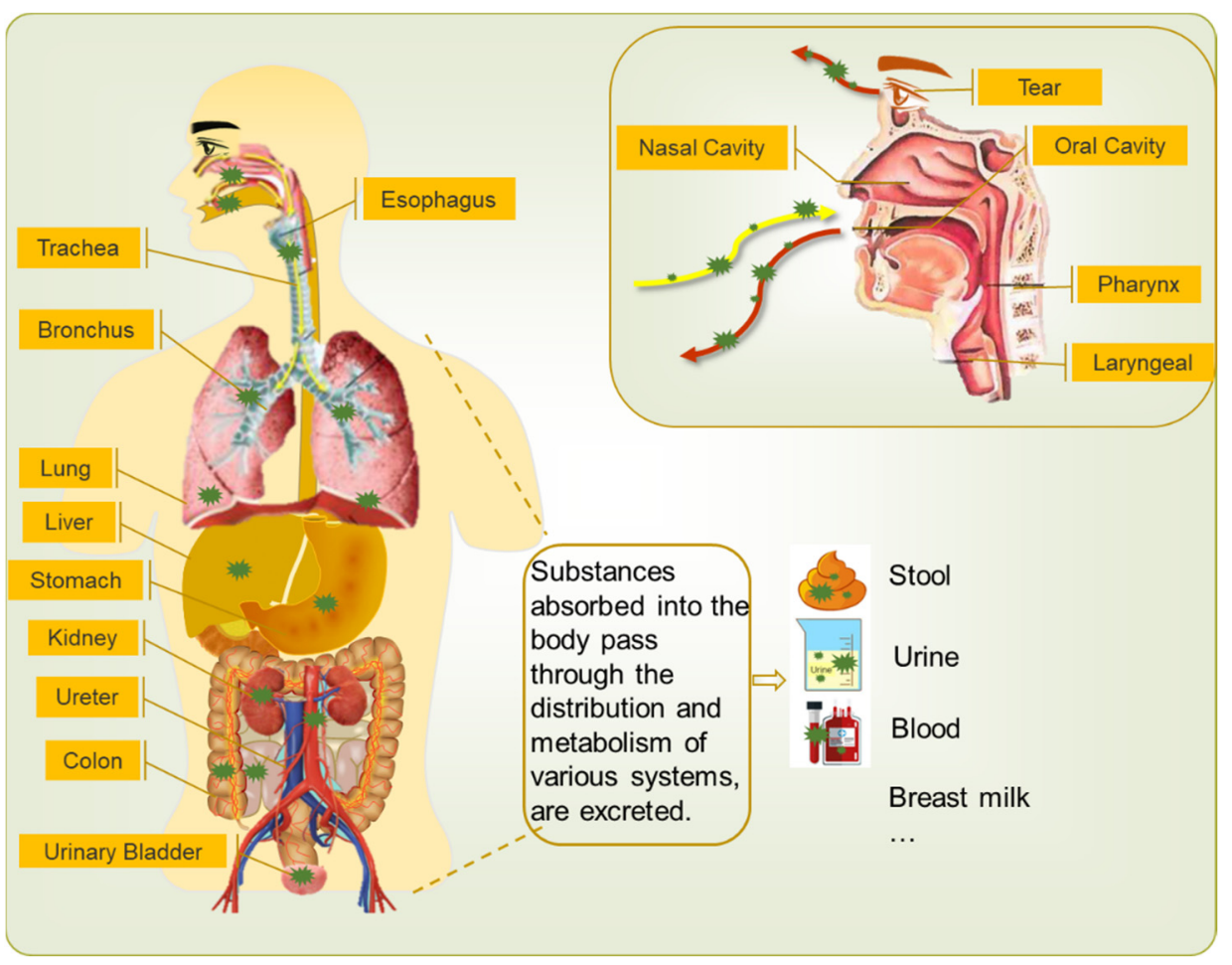

Figure 1. Schematic diagram showing the existence and secretion of virus in a human body. Coronavirus can enter our body through nose and mouth when we are eating, breathing, and so on. It can exist in the organs such as trachea, bronchus, lung, liver, stomach, kidney, and so on. The metabolites and excreta test positive for coronavirus, including tear, stool, urine, blood, breast milk, sputum, and droplets or aerosol from nose and mouth.

The positive results in these samples show the potential modes of virus invasion, albeit, other ways of infection should not be ignored. The expert, Guangfa Wang, deemed it was through his conjunctivitis of eyes that he was infected while working in Wuhan [24,25]. Attention should be paid to the fact that very few positive results ( 1 out of 45 diagnosed patients; 35 males, 10 females; the mean age was $31.26 \pm 21.81$ years) were detected from conjunctival swab specimens of COVID-19 patients in South India in April 2020 [26]. It is speculated that infection through eye exudates is a possible way but not the main mode of transmission, yet it still needs attention in daily protection. Regarding SARS-CoV, tear samples were collected from eight patients (four males, four females; mean age was 48.6 years) who were confirmed of having SARS by serology in Singapore, Tan Tock Seng Hospital, on 7-18 April 2003. Three (37.5\%) were positive results [27]. As a high-risk group, whether an infected pregnant mother-to-be can infect the fetus is in focus. Research in this area is often difficult to launch on a large scale due to the particularity of the samples. There were few reports on this in March 2020 [28-35]. There was the case where a female neonate $(2.6 \mathrm{~kg})$ was born by cesarean section to a 25-year-old mother with confirmed COVID-19 [28]. The SARS-CoV-2 nucleic acid tests of the mother's specimens (amniotic fluid, vaginal secretions, cord blood, placenta, serum, anal swab, and breast milk) and the female preterm infant's samples (throat and anal swab, serum, bronchoalveolar lavage fluid, and urine) were all negative [28], so the authors confirmed that "the vertical transmission of COVID is unlikely, but still, more evidence is needed" [28]. Another case, regarding 13 pregnant women, showed that 13 specimens from the mothers' vaginal secretion, five throat swabs from the neonates, and four anal swabs from infants tested negative for SARS-CoV-2 through real-time reverse transcription-polymerase chain reaction assays [30]. Liu et al. thought that there was no vertical transmission of SARS-CoV-2 based on their study that SARS-CoV-2 RT-PCR in all neonates' samples (throat swab, urine, feces) and the mothers' (10 mothers confirmed COVID-19) specimens (breast milk, amniotic) were all negative [34]. 
However, in April 2020, Alzamora et al. found that the neonatal nasopharyngeal swab (the infant was born to a 41-year old mother) was positive for SARS-CoV-2 through RTPCR [29]. This was the earliest reported positive result in the infant [29]. In [28,30,33-35], the SARS-CoV-2 nucleic acid tests of the infants were negative though RT-PCR, while testing positive in [29]. The immunoglobulin IgM and IgG of the neonates for SARS-CoV-2 were negative in [29], and the SARS-CoV-2 lgG and lgM level were all high in the infants and mothers in [35]. Different methods used for diagnosing COVID-19, which include RT-PCR, serologic criteria, and clinical diagnosis, have different sensitivity and specificity. The rapid detection speed of the RT-PCR method is suitable for the sudden increase in the number of infections. To make an accurate diagnosis, a combination of different methods is required. Still, it is necessary to take appropriate precautions at birth. Neonatal isolation is a good way to avoid delayed cord clamping or skin-to-skin contact [29]. In addition, no breastfeeding is required, especially for virus-positive breast milk [30]. High evidence verified that the armpit sweat odor of COVID-19-infected people is different, and dogs can distinguish and detect it [36]. This result showed something different in the sweat from infected patients, which is worth further study. There is no evidence that the coronavirus can be transmitted sexually, and there are negative results in male semen $[37,38]$ and female vaginal discharge [30].

These aforementioned ways may produce the solids, liquids, droplets, and aerosols with the infective virus, while there are specific circumstances that give rise to aerosols carrying the virus within the relevant medical treatment process in the hospital, called aerosol-generating procedures, such as endoscopy, colonoscopy, and the processes of collecting and treating blood with virus. When examined with an endoscope, the patient's contaminated fluid often splashes. During colonoscopy, the patient's saliva can contaminate the pillow or bed, and the mixtures of stool and water often drip onto the bed [39], which may be potential ways to spread virus.

In addition to human beings, animals are another important host of virus. SARS-CoV-2, SARS-CoV, and MERS-CoV probably originate from a bat species [1,7]. SARS-CoV RNA in 6 of 28 fecal specimens from bats were found [40] in North America in August 2006. Besides humans, susceptible pets, livestock, and poultry with hyperkinetic characteristics are also of concern because of their susceptibility to SARS-CoV-2. Researchers [41] investigated the susceptibility to SARS-CoV-2 of cats and dogs for their close contact with people, and ferrets were used in this research as an animal model. Results showed that ferrets and cats were susceptible to SARS-CoV-2, dogs had low susceptibility, and livestock, including chicken, pigs, and ducks had no susceptibility to the virus. Attention should be paid to the interactions with wild and domestic animals during the outbreak.

\subsubsection{The Spread of Droplets Carrying Virus in the Indoor Environment}

The settlement and suspension of droplets from infected people can potentially induce short-distance infection. The number and size of droplets vary significantly. It was estimated that there is a total of 40,000 droplets from a sneeze [42] and approximately 3000 droplet nuclei from a cough [16]. Droplets travel over a wide range of distances, from $0 \mathrm{~m}$ to $6 \mathrm{~m}$ and even further. The factors affecting the dispersion, deposition, and the survival of microorganisms within the droplets can be the internal factors (size, constitution) and external factors (expiratory flow, room airflow, and Brownian motion), in which the size is regarded as the most important [16]. Aerosols or droplets exhaled from various parts of the human respiratory system, and different exhaling behaviors, such as breath, speaking, coughing, and sneezing, have a wide range of diameter (see Figure 2). Large droplets generated by breath can travel a short distance of 1.5-2 $\mathrm{m}$ [43], and are deposited on the ground quickly. They can be carried over $6 \mathrm{~m}$ by exhaled air at a velocity of $50 \mathrm{~m} / \mathrm{s}$ (sneezing), over $2 \mathrm{~m}$ at a velocity of $10 \mathrm{~m} / \mathrm{s}$ (coughing), and less than $1 \mathrm{~m}$ away at a velocity of $1 \mathrm{~m} / \mathrm{s}$ (breathing) [43]. 


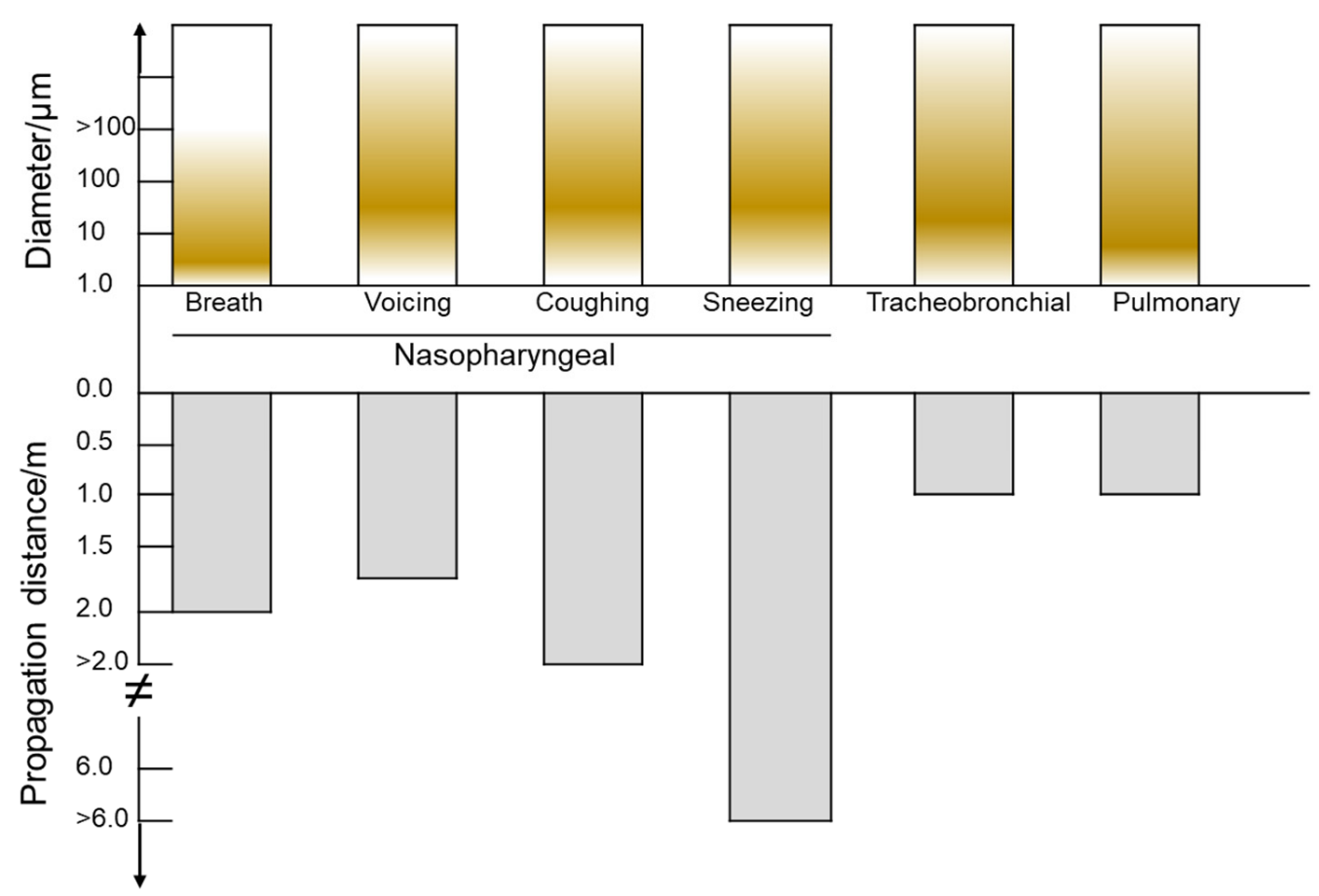

Figure 2. The diameter, density, and propagation distance of droplets generated by different parts of the respiratory system, which are nasopharyngeal (breath, speaking, coughing, sneezing), tracheobronchial, and pulmonary. The upper part of the picture reveals that different sources give rise to characteristic ranges of droplets' sizes. The darker the color, the more droplets are produced. The lower part of the picture shows that the droplets can be transmitted to various ranges of distance $[16,43-45]$.

Droplets from infected people can likely contaminate the surroundings, such as sofas, chairs, beds, carpets, stairs, glass, tables, kitchen utensils, bathroom utensils, etc., in living environments, centrifuge, electronic balance, beaker, conical flask, thermometer, acid/base burette, etc., in labs, stethoscope, CT machine, chest X-ray machine, seat, etc., in hospitals, and public printer, public water dispenser, public toilet, and other public office equipment in office blocks. There are also some special spaces, such as flights, cruise ships, prisons, churches, or buses. They are such relatively closed and confined spaces for a certain period of time, causing the virus to spread more widely and quickly [46]. From 24 January to 4 February 2020, investigators [20] took environmental surface samples in the infection isolation rooms of hospitals in Singapore, including the bed, the bed's accessory, chair, toilet, sink, bathroom, doors, light switches, floor, windows, and so on, obtaining $61 \%$ positive results in all samples. While seeking treatment in several healthcare facilities, a patient with the virus caused 186 MERS-CoV infections within 10 days in South Korea in July 2015 [47]. Nosocomial outbreaks are the transmission scenarios amplified, which can be called super-spreading events [47], so it is necessary for healthcare workers and nonclinical hospital staff to take measures to protect themselves. The outbreak of COVID-19 has put forward higher requirements and challenges in laboratory safety, especially the laboratory testing related viruses. On 12 February 2020, the sampling of a nucleic acid testing laboratory environment was conducted in the Taihe Hospital in Shiyan City, Hubei Province, China [48]. There were $21.3 \%$ (13/61) of sample transportations and receptionrelated facilities, testing related instruments, personal protective equipment, and other facilities in the nucleic acid testing laboratory that tested positive with SARS-CoV-2, and the main contamination method in a lab environment may be hand contact [48], which is a short-distance transmission. Olsen et al. [49] investigated the possibility of the SARS-CoV spreading on flights during the early outbreak of SARS in 2003, and concluded that the virus was likely to spread on flights through aerosol and small droplets. As for these 
possible transmission routes, we can take some measures to prevent the spread of the virus at an early stage, such as reducing activities, setting up quarantine areas, wearing personal protective equipment, disinfection, etc. After the outbreak of COVID-19, governments took the current limitations of using facemasks, good ventilation, and disinfection and sterilization measures to public places. The probability of virus transmission in these public places after taking these measures plays an important role in epidemic prevention and control. Conte et al. collected aerosol samples in different indoor community environments in Veneto, Emilia-Romagna, and Puglia, Italy. All of them tested negative for SARS-CoV2 [50], suggesting that these measures are important for reducing the airborne transmission of SARS-CoV-2.

Small droplets evaporate rapidly, whereas large droplets, depositing soon after release, take a longer time to evaporate [16,43]. Both evaporation and airflow clearly contribute to transporting droplets. The deposition and suspension of droplets in the living environment is shown in Figure 3. Among them, the sanitary facilities' ventilation systems should be given greater attention. They are major factors of virus propagation for connecting to the sewage system contaminated by the excretion from the infected humans, and they can cause indoor dynamics that cause drainage of contaminated fluids to form aerosols or small droplets [51]. In March 2003, Yu et al. analyzed the spread of the SARS-CoV in Amoy Gardens in Hong Kong. They found extremely high concentrations of SARS-CoV inside the drainage pipes, and the feces and urine from the patients, which likely generated lots of virus-laden aerosols with the help of the hydraulic action [52]. Their studies support the probability of an airborne transmission of SARS-CoV. A large community outbreak of SARS$\mathrm{CoV}$ in Amoy Gardens, Hong Kong, indicated the possibility of airborne transmission of the virus, and investigations showed that the sewage-disposal system, the ventilation system, and human-to-human contact, as well as communal facilities, led to the spread of infection in the units of buildings and the whole housing estate $[16,53]$. Regarding the turbulence induced by human bodies, researchers [16] detailed the effect of human walking and body plumes on the indoor airflow. The movement of the limbs and trunk of the human body, and the movement of the door to open/close it etc., create vortices that cause the indoor airflow to transmit droplets with virus. The body thermal plume can create a thin layer of turbulence around the body which entrains and transports pollutants from the lower part of the human body, such as on the floor, on the stairs, and so on [54]. We use the living environment as an example to illustrate (Figure 3) how the virus might spread indoors, and the factors that influence it.

Whether droplets carrying virus can become long-distance transmitters is dependent on how long the droplets can reside in the air (as described above), whether these droplets can be acquired by the susceptible hosts, and how long the virus in droplets remains infectious [55]. A lot of environmental factors may affect the virus survival, which were summarized by Tang [56], especially for the temperature and relative humidity. Here, we summarize the furniture and equipment where the virus may exist and summarize the survival time of the virus on them, as follows (Table 1). 


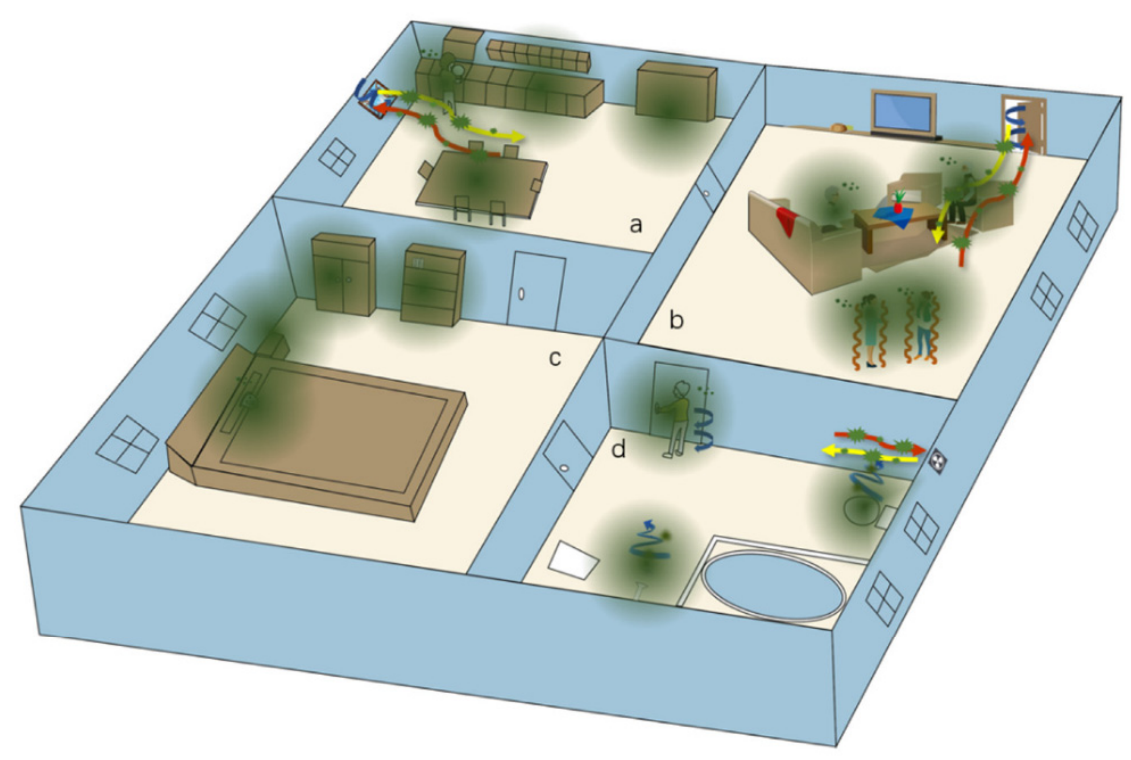

Note:

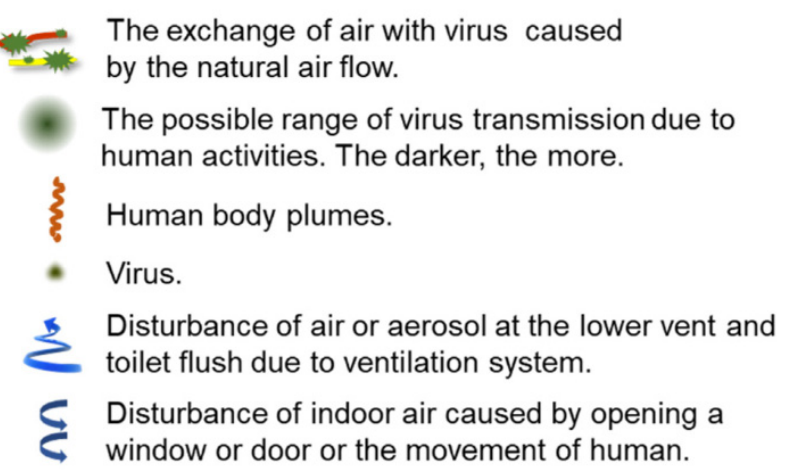

Figure 3. People's different behaviors in different parts of the family may be ways of spreading the virus. (a) Cooking and eating in the kitchen; (b) Chatting in the living room; (c) Sleeping in the bedroom; (d) Washing, bathing, and using the toilet in the bathroom. Ventilation system and heating system of the home, and the movements of doors, windows, and people drive the flow of indoor air, and the virus also spreads. The body thermal plume creates a thin layer of turbulence around the body, and entrains and transports pollutants around the human body.

Table 1. The virus survival time (d) on different textures in indoor environment.

\begin{tabular}{|c|c|c|c|c|c|}
\hline $\begin{array}{c}\text { Indoor } \\
\text { Environment }\end{array}$ & Furniture/Equipment & Texture & $\begin{array}{l}\text { Virus Survival } \\
\text { Time (d) }\end{array}$ & Influence Factor & Reference \\
\hline \multirow{5}{*}{ House } & sofa & leather, fabric, wood & $\begin{array}{l}\text { 1-2 (woodiness } \\
\text { and fabric) }\end{array}$ & $\begin{array}{l}\text { temperature and } \\
\text { humidity }\end{array}$ & [57] \\
\hline & chair & $\begin{array}{l}\text { leather, wood, steal, } \\
\text { fabric, wood-plastic }\end{array}$ & $\begin{array}{c}\text { 3-4 (stainless steel) } \\
1-2 \text { (woodiness) }\end{array}$ & $\begin{array}{l}\text { temperature and } \\
\text { humidity }\end{array}$ & {$[57,58]$} \\
\hline & table & $\begin{array}{c}\text { artificial marble, solid } \\
\text { wood, glass, }\end{array}$ & $\begin{array}{c}1-2 \text { (woodiness) } \\
2 \text { (glass) }\end{array}$ & $\begin{array}{l}\text { temperature and } \\
\text { humidity }\end{array}$ & [57] \\
\hline & bed/mattress & sponge, latex & $\begin{array}{l}3 \text { (sponge) } \\
6 \text { (latex) }\end{array}$ & $\begin{array}{l}\text { temperature and } \\
\text { humidity }\end{array}$ & [59] \\
\hline & carpet & $\begin{array}{l}\text { wool, propylene, } \\
\text { nylon, hemp, and } \\
\text { mixed fabric }\end{array}$ & 1 (cotton) & $\begin{array}{l}\text { temperature and } \\
\text { humidity }\end{array}$ & [60] \\
\hline
\end{tabular}


Table 1. Cont.

\begin{tabular}{|c|c|c|c|c|c|}
\hline $\begin{array}{c}\text { Indoor } \\
\text { Environment }\end{array}$ & Furniture/Equipment & Texture & $\begin{array}{l}\text { Virus Survival } \\
\text { Time (d) }\end{array}$ & Influence Factor & Reference \\
\hline & cup & $\begin{array}{c}\text { glass, porcelain, } \\
\text { stainless steel, plastic }\end{array}$ & $\begin{array}{c}\text { 3-4 (plastic and } \\
\text { stainless steel) } \\
5 \text { (porcelain) }\end{array}$ & $\begin{array}{l}\text { temperature and } \\
\text { humidity }\end{array}$ & {$[57,58,61]$} \\
\hline & toothbrush & $\begin{array}{l}\text { willow, bristle, } \\
\text { artificial wool brush }\end{array}$ & $4-6$ & $\begin{array}{l}\text { temperature and } \\
\text { humidity }\end{array}$ & {$[61,62]$} \\
\hline \multirow{6}{*}{ Lab } & centrifugal machine & stainless steel & 3-4 (stainless steel) & $\begin{array}{l}\text { temperature and } \\
\text { humidity }\end{array}$ & [58] \\
\hline & electronic balance & stainless steel & 3-4 (stainless steel) & $\begin{array}{l}\text { temperature and } \\
\text { humidity }\end{array}$ & [58] \\
\hline & beaker & glass & 2 (glass) & $\begin{array}{l}\text { temperature and } \\
\text { humidity }\end{array}$ & [57] \\
\hline & conical flask & glass & 2 (glass) & $\begin{array}{l}\text { temperature and } \\
\text { humidity }\end{array}$ & [57] \\
\hline & thermometer & glass surface & 2 (glass) & $\begin{array}{l}\text { temperature and } \\
\text { humidity }\end{array}$ & [57] \\
\hline & acid/base burette & glass surface & 2 (glass) & $\begin{array}{l}\text { temperature and } \\
\text { humidity }\end{array}$ & [57] \\
\hline \multirow{3}{*}{ Hospital } & stethoscope & metal & - & - & - \\
\hline & chest $\mathrm{X}$-ray machine & compound material & - & - & - \\
\hline & public seat & plastic & 3-4 (plastic) & $\begin{array}{l}\text { temperature and } \\
\text { humidity }\end{array}$ & [57] \\
\hline \multirow{3}{*}{ Office Block } & public printer & plastic & 3-4 (plastic) & $\begin{array}{l}\text { temperature and } \\
\text { humidity }\end{array}$ & [57] \\
\hline & $\begin{array}{l}\text { public water } \\
\text { dispenser }\end{array}$ & plastic & 3-4 (plastic) & $\begin{array}{l}\text { temperature and } \\
\text { humidity }\end{array}$ & [57] \\
\hline & public toilet & marble & & & \\
\hline
\end{tabular}

\subsubsection{The Present Form and Survival Time of Virus on Solid Surfaces}

The survival time and transmission of the virus in the environment are affected by many factors, of which the characteristics of the virus itself and the characteristics of the external environment are important factors [63]. We summarize reports on SARS-CoV-2 and other coronaviruses because there is little data on the survival of SARS-CoV-2 on environmental surfaces. There are more detailed introductions about the existence form and survival time of virus in different environment (water and air) in Section 2.

\section{Persistence of Virus on Nonporous Surfaces}

The survival time of SARS-CoV-2 on different nonporous surfaces is different. At room temperature and relative humidity of $65 \%$ plastic products, SARS-CoV- 2 also maintains the ability to infect, with a maximum survival time of 7 days [57]. The survival time varies on different metal surfaces. The alloys of copper and copper have bactericidal activity, so the survival time of coronaviruses on the surface of metals with high copper content is short. For example, coronaviruses survive for $8 \mathrm{~h}$ on copper nickel and brass surfaces but only 3 days on stainless-steel surfaces $[58,64,65]$.

Persistence of Virus on Porous Surfaces

The survival time of SARS-CoV-2 on different porous surfaces is different, and the rule is that the survival time on surfaces with high porosity is higher than that on surfaces with low porosity. The survival time in the inner and outer layers of a surgical mask was 4 days 
and 7 days, respectively, and the survival time on a cloth and banknote was 2 days and 1 day, respectively. However, it can only survive for $30 \mathrm{~min}$ on paper with low porosity [57].

\subsection{Transmission Routes of Virus in the Outdoor Environment}

Virus shedding from humans and animals can enter the outdoor environment directly or indirectly, especially via the three wastes (Figure 4). The survival time and infectivity of a virus after leaving the hosts play a crucial role in the transmission of the virus [66-68]. During the alive and infectious time, the virus can spread across the outdoor environment to infect the next host.

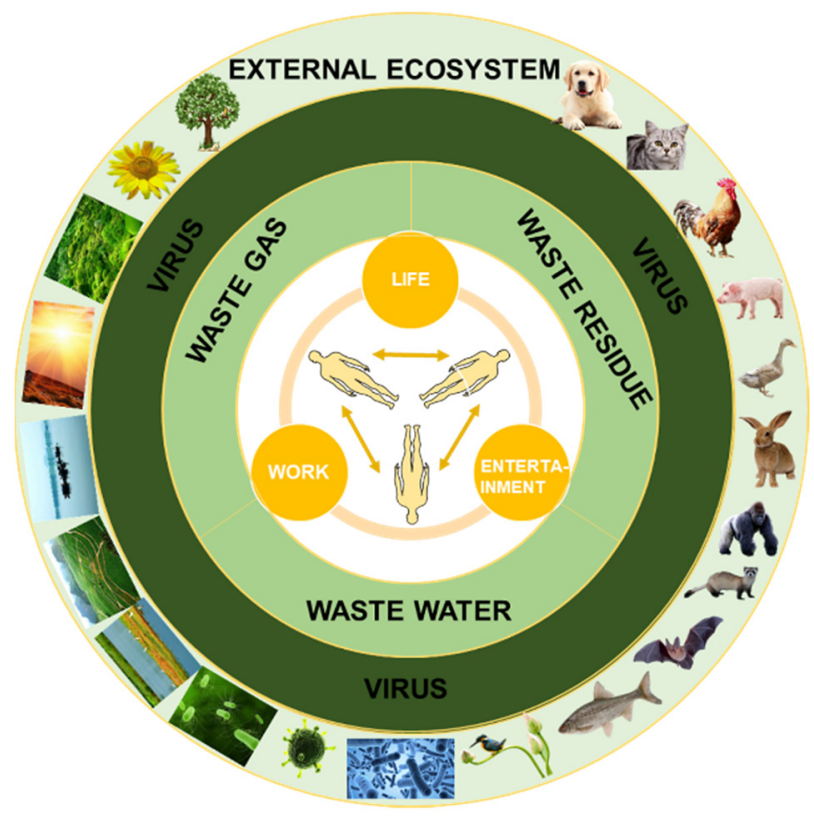

Figure 4. A brief diagram of virus spread from people's life, work, and entertainment to the external environment via three wastes containing virus.

If the viruses are shed in the feces in the areas of vast infected populations, such as hospitals and residential areas, as well as isolation areas, numerous sewages carrying the viruses could be deposited into municipal sewage systems which become a potential source of infection. Since the outbreak of new coronavirus, many research groups have found traces of the virus in sewage in America, the Netherlands, and Sweden [69], and the authors pointed out that wastewater testing could also be used as an early warning sign if the virus returns. In the collection pipelines before reaching the wastewater treatment plants, partial sewage infected by virus may seep into the groundwater due to the rupture of the pipeline, leading to the infection of the groundwater. Sewage sludge, the product of the wastewater treatment plants, is mostly applied to agricultural land in America [70] and it contains a much greater number of pathogens than other environments and wastewater samples [70]. Aerosols from activated sludge process also have high probability of spreading SARS-CoV2; beyond that, rain water, snow melt water, flood water, and the septic tanks, which do not disinfect the effluent, absolutely can contaminate the water bodies, through shallow groundwater depth, areas having no access to water treatment facilities, flood-prone areas, and the drinking water source within a radius of $30 \mathrm{~m}$ from the septic tank without appropriate precautions [53], causing the further spreading of SARS-CoV-2. Wildlife becomes infected by contact with the contaminated natural aquatic environment, which have been illustrated in two mechanisms [71], indicating the high risk of infection with wildlife in this way. Many species of wildlife drink or take baths from open bodies of water which are contaminated heavily, especially artificial water such as catchments in wastewater treatment plants, reservoirs, canals, water from mining, and similar, so they are at great risk of virus infection. Natural water bodies (such as pools, lakes, ponds, streams, 
and rivers) and artificial water bodies (such as farm and urban dams, canals, cattle troughs, swimming pools, settling ponds at wastewater treatment facilities, and mines with natural seepage) are the drinking water sources of bats [72], which have a wide range of overlap with humans. It is possible that both wild and domestic animals can be the hosts of the virus and spread the virus. Therefore, the virus will cycle and cause infection in the natural aquatic environment through the collection, treatment, and discharge of sewage.

In addition to wastewater, solid waste and gas waste are also important ways to spread the virus. Investigations show that the mismanagement of municipal solid waste could increase the second virus outbreak [73]. It is obvious that there are vast and messy dispersions of abandoned masks and gloves in the indoors and outdoors since the SARSCoV-2 outbreak. The generation, collection, transportation, and disposal of garbage with viruses can transmit the virus if they are mishandled. Researchers [73] investigated the relationship between the mutual implications of waste management and COVID-19 in Italy after taking measures enacted by the government, finding useful solutions to tackle COVID-19 in the municipal solid waste management sector. As for the airborne infection, on the one hand, the virus-bearing gas discharged outside through the ventilation system may reach the surface runoff with rainfall and snowfall, or it may settle, from which it will be infective, flowing downstream through water and solids. On the other hand, the direct airborne transmission is considered by many researchers as one of the most important ways to spread the virus in a mass distribution [16,51,52,74]. Besides, the style of modern life can affect the way of infection. The rise of the sharing economy, such as shared bikes, shared cars, and shared umbrellas, is emerging in some big cities. The use of these shared facilities increases direct and indirect contact between people and the spread of the virus at the same time [2].

Closed indoor space is the main place where the virus leaves the hosts and enters the indoor environment. Indoor environments, especially settings where there is poor or no ventilation, are riskier than outdoor environments. WHO state that the virus transmission can occur more easily in the "three Cs": (1) Crowded places with many people nearby; (2) Close-contact settings, especially where people have conversations very close to each other; (3) Confined and enclosed spaces with poor ventilation [75]. A safe distance of $1 \mathrm{~m}$ is often taken in indoor and outdoor environments, which merely applies to specific organisms and epidemiological studies [76]. Some strict quarantine measures are implemented in many areas. Once the virus spreads, its influence scope will be very large, especially through the air and water that human beings depend on for survival.

\subsection{The Impact of Environmental Factors on the Stability and Transmission of Virus}

Most of the respiratory viruses that cause aspiration diseases can be airborne as the host breathes and talks $[77,78]$. As a carrier of virus transmission, small droplets are affected by environmental factors. Accumulating studies point to the idea that environmental factors can influence the likelihood of an outbreak of viruses to some extent, including temperature [79,80], humidity [81-84], wind speed [85], and air pollution [86-89].

In general, data analysis and simulated control have been used to study the correlation between environmental factors and diseases. Tian Yaohua and his colleagues used case information from 8834,533 cases in 184 cities in China from 1 January 2014, to 31 December 2017, and corresponding pollution data for fine particulate matter in the environment, applying quasi-Poisson regression in a generalized additive model (GAM) and random effects meta-analyses to estimate the average association between regional and national PM2.5 levels and daily hospital admissions for cardiovascular disease [90].

Instead of analyzing the data, Eriko Kudo and his team used the model of Mx1 mice. Controlled for humidity, Mx1 homologous mice reared in low relative humidity were more susceptible to severe disease after challenge by influenza virus [82].

Since the outbreak of COVID-19, entering the keyword "COVID-19" in Web of Science (http: / / webofscience.com, accessed on 25 November 2021) returns about 42,000 articles (as of 17 August 2020). Many of the researchers have focused on the correlation between 
environmental factors and COVID-19; most studies draw statistical conclusions based on epidemiological data, but different studies may draw conflicting correlations. The study by Takagi and his team, for example, found a negative correlation between temperature and the incidence of COVID-19 [91], while Tosepu and his colleagues found a positive correlation [92]. In our previous study [93], we used epidemiological and meteorological data from eight regions of South America to show a negative correlation between absolute humidity and epidemic spread through regression analysis.

\subsection{The Emergence and Spread of SARS-CoV-2 Variants of Concern}

All viruses mutate for the deletions, insertions, or substitutions of nucleotides [94]. Environmental selection and viral fitness pick adaptable dominant mutant viruses, making them more common. Understanding these mutant strains, figuring out the evolutionary process of the mutants, which mutations are important, and how to minimize their impact are what we need to expand gradually. SARS-CoV-2 is enveloped single-stranded RNA, that is highly diverse and can alter its genome sequence during replication in host cells [95]. SARS-CoV-2 variants first started emerging in early March 2020, and variants become predominant since June 2020 [96]. For now, several specific viral lineages reflecting SARSCoV-2 variants of concern (VOCs) have emerged and are of public health concern, which are B.1.1.7 (first identified in the UK in December 2020, Alpha variant), B.1.351 (first detected in the Republic of South Africa in December 2020, Beta variant), P.1 (first identified in travelers from Brazil in December 2020, Gamma variant) [97], and B.1.617.2 (surged in India in early 2021, Delta variant) [98]. More transmission and lower vaccine efficacy than the previous nonvariant viruses have been studied [98-102]. During 16-23 December 2020, in Zambia, among the 23 specimens collected, 22 (96\%) were the B.1.351 variant [99]. Between November 2020 and January 2021, Faria et al. analyzed the samples from Manaus, Brazil. They identified the VOCs P.1 and estimate that P.1 may be 1.4-2.2 times more transmissible and $25-61 \%$ more likely to evade protective immunity elicited by previous infection with non-P.1 lineages [103]. The vaccines effectiveness (evade immunity induced by vaccination or not), reinfection rates, hospitalization, toxicity, mortality, and the risk of death caused by the VOCs is in focus while they have not been figured out. Therefore, these VOCs are still suitable for the abovementioned possible means of virus transmission. Before the emergence of an exact treatment method, the use of nonvaccine methods, such as physical isolation, is still an indispensable protective measure. There is a remarkable example where, with the increase in social distancing caused by the third England lockdown, the transmission declined [102].

\section{The Existence Form and Survival Time of Virus in Different Environments}

\subsection{The Existence Form and Survival Time of Virus in Water}

Water can provide a vector for pathogen transmission and create conditions for outbreaks or sporadic infections, especially after fecal contamination. A large proportion of human diseases are detected in the water and are thought to be responsible for a considerable proportion of waterborne diseases [104-109].

There are certain differences in the stability and survival time of coronaviruses in different water environments. Field studies have monitored coronaviruses in surface waters, sewage, slurry, and biosolids. Overall, at the lab scale, HCoVs or surrogates can survive for several days at $4^{\circ} \mathrm{C}$; however, their persistence is lower compared with nonenveloped viruses and is strongly influenced by temperature and organic or microbial pollution [110].

At room temperature, SARS-CoV-1 suspended in untreated water remained detectable for 3 days and was not detected after 5 days [111]. It takes 2-3 days to reduce the amount of coronavirus in the wastewater without high-temperature disinfection by $99.9 \%$. Under the same conditions, the survival time of coronavirus in water at $4{ }^{\circ} \mathrm{C}$ was 14 days [112]. In another study, we found that chlorination and decolorization of tap water at room 
temperature lasted only two days and completely decayed in three days [112]. However, the survival time of coronavirus in water treated at $4{ }^{\circ} \mathrm{C}$ was 14 days [112].

In the latest study, SARS-CoV-2 virus RNA was detected even in the treated wastewater. However, the presence of viral RNA does not indicate that these virus particles are complete and infectious. The transmission of COVID-19 through fecal oral route has not been confirmed, and the occurrence of SARS-CoV-2 in water environment has not been confirmed [113].

\subsection{Airborne Form and Survival Time of Virus}

In life, coronaviruses may enter the air by sneezing or coughing and exist as aerosols [114-118]. Aerosols carrying new-crowned viruses are airborne suspensions that are constrained by physical and biological laws, where particle size is an important determinant of aerosol behavior [119]. The traditional view is that most respiratory infections are transmitted by droplets (greater than $5 \mu \mathrm{m}$ ) produced by coughing and sneezing [120]. However, particles 5 microns or smaller in size can remain in the air for a long time under most indoor conditions [121]. Most particles with influenza virus RNA (87\%) were found to be less than 1 micron after aerosol particle size measurements of exhaled virus particles [122], and it can survive in the air for a long time and spread with distance. Aerosols with small particle sizes are, therefore, the main form of airborne transmission of newly crowned viruses [123-126]. The temperature and humidity under the same particle size are important determinants. The higher the temperature, the smaller the half-life, and the half-life under different humidity is also different. SARS-CoV-2 decays more rapidly when temperature or humidity increases [127], and influenza virus in stationary droplets remains infectious at all relative humidities (RHs) [128].

\section{Summary and Perspectives}

COVID-19 is a great threat to humans all over the world, and coercive means have been implemented to control it, but some of the work is inefficient due to the lack of a complete understanding of SARS-CoV-2. Our work gives a summary of the possible transmission means and the survival time of the virus, as well as their influence factors. We think that person-to-person transmission and airborne transmission are possible.

Now, we are in the post-epidemic era. Whether this situation remains for a long time is not known. There is still much research for human beings to carry out. We recommend carrying out the following research in the next $2-5$ years: I. The exact source of SARS-CoV-2: We are just speculating on the source of the virus without conclusive evidence for now. II. Judgment and prediction of the mutation direction of the virus. III. A proven vaccine. IV. Establish a long-term mechanism for early warning and prevention of public health emergencies. This epidemic has lasted for 2 years. At the beginning, people everywhere were in panic, and were mentally and physically under tremendous pressure. As everyone worked together to fight COVID-19, the epidemic has gradually eased. Although there is no thorough interference from SARS-CoV-2, people have adapted to life, study, and work under COVID-19. What we should do is learn from this experience and come together without borders.

Author Contributions: X.X.: visualization, investigation, and writing; J.Z.: visualization, investigation, and writing; L.Z.: investigation and writing; Q.H.: conceptualization, validation, and supervision. All authors have read and agreed to the published version of the manuscript.

Funding: This work was supported by the National Key R\&D Program of China (2018YFE0103300), the International Partnership Program of Chinese Academy of Sciences (132C35KYSB20200012).

Institutional Review Board Statement: Not applicable.

Informed Consent Statement: Not applicable.

Data Availability Statement: The data we quoted have been attributed in the article. Data set available on request to corresponding authors. 
Conflicts of Interest: The authors declare no conflict of interest.

\section{References}

1. Rehman, S.U.; Shafique, L.; Ihsan, A.; Liu, Q. Evolutionary Trajectory for the Emergence of Novel Coronavirus SARS-CoV-2. Pathogens 2020, 9, 240. [CrossRef] [PubMed]

2. Dietz, L.; Horve, P.F.; Coil, D.A.; Fretz, M.; Eisen, J.A.; Van Den Wymelenberg, K. 2019 Novel Coronavirus (COVID-19) Pandemic: Built Environment Considerations To Reduce Transmission. mSystems 2020, 5, e00245-20. [CrossRef]

3. Acuti Martellucci, C.; Flacco, M.E.; Cappadona, R.; Bravi, F.; Mantovani, L.; Manzoli, L. SARS-CoV-2 pandemic: An overview. Adv. Biol. Regul. 2020, 77, 100736. [CrossRef]

4. $\quad$ Faridi, S.; Niazi, S.; Sadeghi, K.; Naddafi, K.; Yavarian, J.; Shamsipour, M.; Jandaghi, N.Z.S.; Sadeghniiat, K.; Nabizadeh, R.; Yunesian, M.; et al. A field indoor air measurement of SARS-CoV-2 in the patient rooms of the largest hospital in Iran. Sci. Total Environ. 2020, 725, 138401. [CrossRef]

5. Woolhouse, M.E.J.; Gowtage-Sequeria, S. Host Range and Emerging and Reemerging Pathogens. Emerg. Infect. Dis. 2005, 11, 1842. [CrossRef]

6. Kan, B.; Wang, M.; Jing, H.; Xu, H.; Jiang, X.; Yan, M.; Liang, W.; Zheng, H.; Wan, K.; Liu, Q.; et al. Molecular evolution analysis and geographic investigation of severe acute respiratory syndrome coronavirus-like virus in palm civets at an animal market and on farms. J. Virol. 2005, 79, 11892-11900. [CrossRef]

7. Ji, W.; Wang, W.; Zhao, X.; Zai, J.; Li, X. Cross-species transmission of the newly identified coronavirus 2019-nCoV. J. Med. Virol. 2020, 92, 433-440. [CrossRef]

8. Kayali, G.; Peiris, M. A more detailed picture of the epidemiology of Middle East respiratory syndrome coronavirus. Lancet Infect. Dis. 2015, 15, 495-497. [CrossRef]

9. Wolfel, R.; Corman, V.M.; Guggemos, W.; Seilmaier, M.; Zange, S.; Muller, M.A.; Niemeyer, D.; Jones, T.C.; Vollmar, P.; Rothe, C.; et al. Virological assessment of hospitalized patients with COVID-2019. Nature 2020, 581, 465. [CrossRef] [PubMed]

10. Wadman, M.; Couzin-Frankel, J.; Kaiser, J.; Matacic, C. How Does Coronavirus kill? Clinicians Trace a Ferocious Rampage through the Body, from Brain to Toes. Available online: https://www.science.org/content/article/how-does-coronavirus-killclinicians-trace-ferocious-rampage-through-body-brain-toes (accessed on 17 April 2020).

11. Belhadjer, Z.; Méot, M.; Bajolle, F.; Khraiche, D.; Legendre, A.; Abakka, S.; Auriau, J.; Grimaud, M.; Oualha, M.; Beghetti, M.; et al. Acute Heart Failure in Multisystem Inflammatory Syndrome in Children in the Context of Global SARS-CoV-2 Pandemic. Circulation 2020, 142, 429-436. [CrossRef] [PubMed]

12. Bryan, A.; Pepper, G.; Wener, M.H.; Fink, S.L.; Morishima, C.; Chaudhary, A.; Jerome, K.R.; Mathias, P.C.; Greninger, A.L. Performance Characteristics of the Abbott Architect SARS-CoV-2 IgG Assay and Seroprevalence in Boise, Idaho. J. Clin. Microbiol. 2020, 58, e00941-20. [CrossRef]

13. Lei, Z.; Cao, H.; Jie, Y.; Huang, Z.; Guo, X.; Chen, J.; Peng, L.; Cao, H.; Dai, X.; Liu, J.; et al. A cross-sectional comparison of epidemiological and clinical features of patients with coronavirus disease (COVID-19) in Wuhan and outside Wuhan, China. Travel. Med. Infect. Dis. 2020, 35, 101664. [CrossRef] [PubMed]

14. Ling, Y.; Xu, S.B.; Lin, Y.X.; Tian, D.; Zhu, Z.Q.; Dai, F.H.; Wu, F.; Song, Z.G.; Huang, W.; Chen, J.; et al. Persistence and clearance of viral RNA in 2019 novel coronavirus disease rehabilitation patients. Chin. Med. J.-Peking 2020, 133, 1039-1043. [CrossRef]

15. Peng, L.; Liu, J.; Xu, W.; Luo, Q.; Chen, D.; Lei, Z.; Huang, Z.; Li, X.; Deng, K.; Lin, B.; et al. SARS-CoV-2 can be detected in urine, blood, anal swabs, and oropharyngeal swabs specimens. J. Med. Virol. 2020. [CrossRef]

16. Wei, J.; Li, Y. Airborne spread of infectious agents in the indoor environment. Am. J. Infect. Control. 2016, 44 (Suppl. 9), S102-S108. [CrossRef]

17. Corman, V.M.; Albarrak, A.M.; Omrani, A.S.; Albarrak, M.M.; Farah, M.E.; Almasri, M.; Muth, D.; Sieberg, A.; Meyer, B.; Assiri, A.M.; et al. Viral Shedding and Antibody Response in 37 Patients With Middle East Respiratory Syndrome Coronavirus Infection. Clin. Infect. Dis. 2016, 62, 477-483. [CrossRef]

18. Colavita, F.; Lapa, D.; Carletti, F.; Lalle, E.; Bordi, L.; Marsella, P.; Nicastri, E.; Bevilacqua, N.; Giancola, M.L.; Corpolongo, A.; et al. SARS-CoV-2 Isolation From Ocular Secretions of a Patient With COVID-19 in Italy With Prolonged Viral RNA Detection. Ann. Intern. Med. 2020, 173, 242-243. [CrossRef] [PubMed]

19. Holshue, M.L.; DeBolt, C.; Lindquist, S.; Lofy, K.H.; Wiesman, J.; Bruce, H.; Spitters, C.; Ericson, K.; Wilkerson, S.; Tural, A.; et al. First Case of 2019 Novel Coronavirus in the United States. N. Engl. J. Med. 2020, 382, 929-936. [CrossRef]

20. Ong, S.W.X.; Tan, Y.K.; Chia, P.Y.; Lee, T.H.; Ng, O.T.; Wong, M.S.Y.; Marimuthu, K. Air, Surface Environmental, and Personal Protective Equipment Contamination by Severe Acute Respiratory Syndrome Coronavirus 2 (SARS-CoV-2) From a Symptomatic Patient. JAMA 2020, 323, 1610-1612. [CrossRef] [PubMed]

21. Young, B.E.; Ong, S.W.X.; Kalimuddin, S.; Low, J.G.; Tan, S.Y.; Loh, J.S.; Ng, O.T.; Marimuthu, K.; Ang, L.W.; Mak, T.M.; et al. Epidemiologic Features and Clinical Course of Patients Infected With SARS-CoV-2 in Singapore. JAMA-J. Am. Med. Assoc. 2020, 323, 1488-1494. [CrossRef]

22. Cheng, P.K.; Wong, D.A.; Tong, L.K.; Ip, S.-M.; Lo, A.C.; Lau, C.-S.; Yeung, E.Y.; Lim, W.W. Viral shedding patterns of coronavirus in patients with probable severe acute respiratory syndrome. Lancet 2004, 363, 1699-1700. [CrossRef]

23. Wang, W.; Xu, Y.; Gao, R. Detection of SARS-CoV-2 in Different Types of Clinical Specimens. JAMA 2020, 323, 1843. [CrossRef] 
24. Seah, I.; Agrawal, R. Can the Coronavirus Disease 2019 (COVID-19) Affect the Eyes? A Review of Coronaviruses and Ocular Implications in Humans and Animals. Ocul. Immunol. Inflamm. 2020, 28, 391-395. [CrossRef]

25. Yan, A. Chinese Expert Who Came down with Wuhan Coronavirus after Saying It was Controllable Thinks He Was Infected through His Eyes. Available online: https:/ / www.scmp.com/news/china/article/3047394/chinese-expert-who-came-downwuhan-coronavirus-after-saying-it-was (accessed on 23 January 2020).

26. Kumar, K.; Prakash, A.A.; Gangasagara, S.B.; Rathod, B.L.S.; Ravi, K.; Rangaiah, A.; Shankar, S.M.; Basawarajappa, S.G.; Bhushan, S.; Neeraja, T.G.; et al. Presence of viral RNA of SARS-CoV-2 in conjunctival swab specimens of COVID-19 patients. Indian J. Ophthalmol. 2020, 68, 1015-1017. [CrossRef] [PubMed]

27. Loon, S.C.; Teoh, S.C.B.; Oon, L.L.E.; Se-Thoe, S.-Y.; Ling, A.-E.; Leo, Y.-S. The severe acute respiratory syndrome coronavirus in tears. Br. J. Ophthalmol. 2004, 88, 861-863. [CrossRef]

28. Peng, Z.; Wang, J.; Mo, Y.; Duan, W.; Xiang, G.; Yi, M.; Bao, L.; Shi, Y. Unlikely SARS-CoV-2 vertical transmission from mother to child: A case report. J. Infect. Public Health 2020, 13, 818-820. [CrossRef] [PubMed]

29. Alzamora, M.C.; Paredes, T.; Caceres, D.; Webb, C.M.; Valdez, L.M.; La Rosa, M. Severe COVID-19 during Pregnancy and Possible Vertical Transmission. Am. J. Perinatol. 2020, 37, 861-865. [CrossRef] [PubMed]

30. Wu, Y.; Liu, C.; Dong, L.; Zhang, C.; Chen, Y.; Liu, J.; Zhang, C.; Duan, C.; Zhang, H.; Mol, B.W.; et al. Coronavirus disease 2019 among pregnant Chinese women: Case series data on the safety of vaginal birth and breastfeeding. BJOG 2020, 127, 1109-1115. [CrossRef]

31. Davanzo, R.; Moro, G.; Sandri, F.; Agosti, M.; Moretti, C.; Mosca, F. Breastfeeding and coronavirus disease-2019: Ad interim indications of the Italian Society of Neonatology endorsed by the Union of European Neonatal \& Perinatal Societies. Matern. Child. Nutr. 2020, 16, e13010. [CrossRef] [PubMed]

32. Kimberlin, D.W.; Stagno, S. Can SARS-CoV-2 Infection Be Acquired In Utero?: More Definitive Evidence Is Needed. JAMA 2020, 323, 1788-1789. [CrossRef]

33. Zeng, H.; Xu, C.; Fan, J.; Tang, Y.; Deng, Q.; Zhang, W.; Long, X. Antibodies in Infants Born to Mothers with COVID-19 Pneumonia. JAMA 2020, 323, 1848-1849. [CrossRef]

34. Liu, W.; Wang, J.; Li, W.B.; Zhou, Z.X.; Liu, S.Y.; Rong, Z.H. Clinical characteristics of 19 neonates born to mothers with COVID-19. Front. Med-Prc. 2020, 14, 193-198. [CrossRef]

35. Dong, L.; Tian, J.; He, S.; Zhu, C.; Wang, J.; Liu, C.; Yang, J. Possible Vertical Transmission of SARS-CoV-2 From an Infected Mother to Her Newborn. JAMA 2020, 323, 1846-1848. [CrossRef]

36. Detection Dogs as a Help in the Detection of COVID-19 Can the Dog Alert on COVID-19 Positive Persons by Sniffing Axillary Sweat Samples? Proof-of-Concept Study. Available online: https://www.biorxiv.org/content/10.1101/2020.06.03.132134v1.full (accessed on 25 November 2021).

37. Holtmann, N.; Edimiris, P.; Andree, M.; Doehmen, C.; Baston-Buest, D.; Adams, O.; Kruessel, J.S.; Bielfeld, A.P. Assessment of SARS-CoV-2 in human semen-a cohort study. Fertil Steril 2020, 114, 233-238. [CrossRef]

38. Paoli, D.; Pallotti, F.; Colangelo, S.; Basilico, F.; Mazzuti, L.; Turriziani, O.; Antonelli, G.; Lenzi, A.; Lombardo, F. Study of SARS-CoV-2 in semen and urine samples of a volunteer with positive naso-pharyngeal swab. J. Endocrinol. Invest. 2020, 43, 1819-1822. [CrossRef]

39. Soetikno, R.; Teoh, A.Y.B.; Kaltenbach, T.; Lau, J.Y.W.; Asokkumar, R.; Cabral-Prodigalidad, P.; Shergill, A. Considerations in performing endoscopy during the COVID-19 pandemic. Gastrointest. Endosc. 2020, 92, 176-183. [CrossRef] [PubMed]

40. Dominguez, S.R.; O'Shea, T.J.; Oko, L.M.; Holmes, K.V. Detection of Group 1 Coronaviruses in Bats in North America. Emerg. Infect. Dis. 2007, 13, 1295-1300. [CrossRef] [PubMed]

41. Shi, J.; Wen, Z.; Zhong, G.; Yang, H.; Wang, C.; Liu, R.; He, X.; Shuai, L.; Sun, Z.; Zhao, Y.; et al. Susceptibility of ferrets, cats, dogs, and other domesticated animals to SARS-coronavirus 2. Science 2020, 368, 1016-1020. [CrossRef]

42. Cole, E.C.; Cook, C.E. Characterization of infectious aerosols in health care facilities An aid to effective engineering controls and preventive strategies. Am. J. Infect. Control 1998, 26, 453-464. [CrossRef]

43. Xie, X.; Li, Y.; Chwang, A.T.Y.; Ho, P.L.; Seto, W.H. How far droplets can move in indoor environments - revisiting the Wells evaporation-falling curve. INDOOR AIR 2007, 17, 211-225. [CrossRef]

44. Roy, C.J.; Milton, D.K. Airborne transmission of communicable infection-the elusive pathway. N. Engl. J. Med. 2004, 350, 1710-1712. [CrossRef] [PubMed]

45. Castillo-Allendes, A.; Contreras-Ruston, F.; Cantor-Cutiva, L.C.; Codino, J.; Guzman, M.; Malebran, C.; Manzano, C.; Pavez, A.; Vaiano, T.; Wilder, F.; et al. Voice Therapy in the Context of the COVID-19 Pandemic: Guidelines for Clinical Practice. J. Voice 2020, 35, 717-727. [CrossRef]

46. Mizumoto, K.; Chowell, G. Transmission potential of the novel coronavirus (COVID-19) onboard the diamond Princess Cruises Ship, 2020. Infect. Dis. Model. 2020, 5, 264-270. [CrossRef]

47. Chowell, G.; Abdirizak, F.; Lee, S.; Lee, J.; Jung, E.; Nishiura, H.; Viboud, C. Transmission characteristics of MERS and SARS in the healthcare setting: A comparative study. BMC Med. 2015, 13, 210. [CrossRef]

48. Lv, J.; Yang, J.; Xue, J.; Zhu, P.; Liu, L.; Li, S. Detection of SARS-CoV-2 RNA residue on object surfaces in nucleic acid testing laboratory using droplet digital PCR. Sci. Total Environ. 2020, 742, 140370. [CrossRef] 
49. Olsen, S.J.; Chang, H.-L.; Cheung, T.Y.-Y.; Tang, A.F.-Y.; Fisk, T.L.; Ooi, S.P.-L.; Kuo, H.-W.; Jiang, D.D.-S.; Chen, K.-T.; Lando, J.; et al. Transmission of the Severe Acute Respiratory Syndrome on Aircraft. N. Engl. J. Med. 2003, 394, 2416-2422. [CrossRef]

50. Conte, M.; Feltracco, M.; Chirizzi, D.; Trabucco, S.; Dinoi, A.; Gregoris, E.; Barbaro, E.; La Bella, G.; Ciccarese, G.; Belosi, F.; et al. Airborne concentrations of SARS-CoV-2 in indoor community environments in Italy. Environ. Sci. Pollut. Res. Int. 2021. [CrossRef] [PubMed]

51. Correia, G.; Rodrigues, L.; Gameiro da Silva, M.; Goncalves, T. Airborne route and bad use of ventilation systems as non-negligible factors in SARS-CoV-2 transmission. Med Hypotheses 2020, 141, 109781. [CrossRef] [PubMed]

52. Yu, I.T.S.; Li, Y.; Wong, T.W.; Tam, W.; Chan, A.T.; Lee, J.H.W.; Leung, D.Y.C.; Ho, T. Evidence of Airborne Transmission of the Severe Acute Respiratory Syndrome Virus. N. Engl. J. Med. 2004, 350, 1731-1739. [CrossRef]

53. Bhowmick, G.D.; Dhar, D.; Nath, D.; Ghangrekar, M.M.; Banerjee, R.; Das, S.; Chatterjee, J. Coronavirus disease 2019 (COVID-19) outbreak some serious consequences with urban and rural water cycle. npj Clean. Water 2020, 3. [CrossRef]

54. Rim, D.; Novoselac, A. Transport of particulate and gaseous pollutants in the vicinity of a human body. Build. Environ. 2009, 44, 1840-1849. [CrossRef]

55. Xu, R.; Cui, B.; Duan, X.; Zhang, P.; Zhou, X.; Yuan, Q. Saliva: Potential diagnostic value and transmission of 2019-nCoV. Int. J. Oral Sci. 2020, 12, 11. [CrossRef]

56. Tang, J.W. The effect of environmental parameters on the survival of airborne infectious agents. J. R. Soc. Interface 2009, 6 (Suppl. 6), S737-S746. [CrossRef] [PubMed]

57. Chin, A.W.H.; Chu, J.T.S.; Perera, M.R.A.; Hui, K.P.Y.; Yen, H.L.; Chan, M.C.W.; Peiris, M.; Poon, L.L.M. Stability of SARS-CoV-2 in different environmental conditions. Lancet Microbe 2020, 1, e10. [CrossRef]

58. Van Doremalen, N.; Bushmaker, T.; Morris, D.H.; Holbrook, M.G.; Gamble, A.; Williamson, B.N.; Tamin, A.; Harcourt, J.L.; Thornburg, N.J.; Gerber, S.I.; et al. Aerosol and surface stability of HCoV-19 (SARS-CoV-2) compared to SARS-CoV-1. medRxiv 2020. [CrossRef]

59. Sizun, J.; Yu, M.W.; Talbot, P.J. Survival of human coronaviruses 229E and OC43 in suspension and after drying onsurfaces: A possible source ofhospital-acquired infections. J. Hosp. Infect. 2000, 46, 55-60. [CrossRef]

60. Lai, M.Y.; Cheng, P.K.; Lim, W.W. Survival of severe acute respiratory syndrome coronavirus. Clin. Infect. Dis. 2005, 41, e67-e71. [CrossRef]

61. Warnes, S.L.; Little, Z.R.; Keevil, C.W. Human Coronavirus 229E Remains Infectious on Common Touch Surface Materials. mBio 2015, 6, e01697-15. [CrossRef] [PubMed]

62. Rabenau, H.F.; Cinatl, J.; Morgenstern, B.; Bauer, G.; Preiser, W.; Doerr, H.W. Stability and inactivation of SARS coronavirus. Med. Microbiol. Immunol. 2005, 194, 1-6. [CrossRef] [PubMed]

63. Wolff, M.; Sattar, S.; Adegbunrin, O.; Tetro, J. Environmental survival and microbicide inactivation of coronaviruses. In Coronaviruses with Special Emphasis on First Insights Concerning SARS; Springer: Birkhäuser, Basel, 2006; pp. 201-212. [CrossRef]

64. Michels, H.; Wilks, S.A.; Noyce, J.C.; Keevil, C.W. Copper Alloys for Human Infectious Disease Control. Available online: https: / / citeseerx.ist.psu.edu/viewdoc/download?doi=10.1.1.559.9650\&rep=rep1\&type=pdf (accessed on 25 November 2021).

65. Warnes, S.L.; Keevil, C. Inactivation of Norovirus on Dry Copper Alloy Surfaces. PLoS ONE 2013, 8, e75017.

66. Liu, W.; Tang, F.; Fontanet, A.; Zhan, L.; Zhao, Q.-M.; Zhang, P.-H.; Wu, X.-M.; Zuo, S.-Q.; Baril, L.; Vabret, A.; et al. Long-term SARS Coronavirus Excretion from Patient Cohort, China. Emerg. Infect. Dis. 2004, 10, 1841-1843. [CrossRef]

67. Chan, K.H.; Peiris, J.S.; Lam, S.Y.; Poon, L.L.; Yuen, K.Y.; Seto, W.H. The Effects of Temperature and Relative Humidity on the Viability of the SARS Coronavirus. Adv. Virol. 2011, 2011, 734690. [CrossRef]

68. Casanova, L.; Rutala, W.A.; Weber, D.J.; Sobsey, M.D. Survival of surrogate coronaviruses in water. Water Res. 2009, 43, 1893-1898. [CrossRef]

69. Mallapaty, S. How sewage could reveal true scale of coronavirus outbreak. Nature 2020, 580, 176-177. [CrossRef]

70. Bibby, K.; Peccia, J. Identification of viral pathogen diversity in sewage sludge by metagenome analysis. Environ. Sci. Technol. 2013, 47, 1945-1951. [CrossRef]

71. Franklin, A.B.; Bevins, S.N. Spillover of SARS-CoV-2 into novel wild hosts in North America: A conceptual model for perpetuation of the pathogen. Sci. Total Environ. 2020, 733, 139358. [CrossRef] [PubMed]

72. Korine, C.; Adams, R.; Russo, D.; Fisher-Phelps, M.; Jacobs, D. Bats and Water: Anthropogenic Alterations Threaten Global Bat Populations. In Bats in the Anthropocene: Conservation of Bats in a Changing World; Springer: Cham, Switzerland, 2016; pp. 215-241. [CrossRef]

73. Ragazzi, M.; Rada, E.C.; Schiavon, M. Municipal solid waste management during the SARS-COV-2 outbreak and lockdown ease: Lessons from Italy. Sci. Total Environ. 2020, 745, 141159. [CrossRef] [PubMed]

74. Tang, J.W.; Gao, C.X.; Cowling, B.J.; Koh, G.C.; Chu, D.; Heilbronn, C.; Lloyd, B.; Pantelic, J.; Nicolle, A.D.; Klettner, C.A.; et al. Absence of detectable influenza RNA transmitted via aerosol during various human respiratory activities-experiments from Singapore and Hong Kong. PLoS ONE 2014, 9, e107338.

75. Available online: https://www.who.int/emergencies/diseases/novel-coronavirus-2019/question-and-answers-hub/q-a-detail/ coronavirus-disease-covid-19 (accessed on 25 November 2021). 
76. Johnson, G.R.; Morawska, L.; Ristovski, Z.D.; Hargreaves, M.; Mengersen, K.; Chao, C.Y.H.; Wan, M.P.; Li, Y.; Xie, X.; Katoshevski, D.; et al. Modality of human expired aerosol size distributions. J. Aerosol Sci. 2011, 42, 839-851. [CrossRef]

77. Guan, W.J.; Ni, Z.Y.; Hu, Y.; Liang, W.H.; Ou, C.Q.; He, J.X.; Liu, L.; Shan, H.; Lei, C.L.; Hui, D.S.C.; et al. Clinical Characteristics of Coronavirus Disease 2019 in China. J. Emerg. Med. 2020, 58, 711-712. [CrossRef] [PubMed]

78. Marr, L.C.; Tang, J.W.; Van Mullekom, J.; Lakdawala, S.S. Mechanistic insights into the effect of humidity on airborne influenza virus survival, transmission and incidence. J. R. Soc. Interface 2019, 16, 20180298. [CrossRef]

79. Lowen, A.C.; Mubareka, S.; Steel, J.; Palese, P. Influenza Virus Transmission Is Dependent on Relative Humidity and Temperature. PLoS Pathog. 2007, 3, e1470-e1476. [CrossRef]

80. Moriyama, M.; Ichinohe, T. High ambient temperature dampens adaptive immune responses to influenza A virus infection. Proc. Natl. Acad. Sci. USA 2019, 116, 3118-3125. [CrossRef]

81. Shaman, J.; Pitzer, V.E.; Viboud, C.; Grenfell, B.T.; Lipsitch, M. Absolute humidity and the seasonal onset of influenza in the continental United States. PLoS Biol. 2010, 8, e1000316. [CrossRef]

82. Kudo, E.; Song, E.; Yockey, L.J.; Rakib, T.; Wong, P.W.; Homer, R.J.; Iwasaki, A. Low ambient humidity impairs barrier function and innate resistance against influenza infection. Proc. Natl. Acad. Sci. USA 2019, 116, 10905-10910. [CrossRef] [PubMed]

83. Otter, J.A.; Donskey, C.; Yezli, S.; Douthwaite, S.; Goldenberg, S.D.; Weber, D.J. Transmission of SARS and MERS coronaviruses and influenza virus in healthcare settings: The possible role of dry surface contamination. J. Hosp. Infect. 2016, 92, 235-250. [CrossRef] [PubMed]

84. Shaman, J.; Kohn, M. Absolute humidity modulates influenza survival, transmission, and seasonality. Proc. Natl. Acad. Sci. USA 2009, 106, 3243-3248. [CrossRef]

85. Peci, A.; Winter, A.L.; Li, Y.; Gnaneshan, S.; Liu, J.; Mubareka, S.; Gubbay, J.B. Effects of Absolute Humidity, Relative Humidity, Temperature, and Wind Speed on Influenza Activity in Toronto, Ontario, Canada. Appl. Environ. Microbiol. 2019, 85, e02426-18. [CrossRef] [PubMed]

86. Adhikari, A.; Yin, J. Short-Term Effects of Ambient Ozone, PM2.5, and Meteorological Factors on COVID-19 Confirmed Cases and Deaths in Queens, New York. Int. J. Environ. Res. Public Health 2020, 17, 4047. [CrossRef] [PubMed]

87. Ali, S.T.; Wu, P.; Cauchemez, S.; He, D.; Fang, V.J.; Cowling, B.J.; Tian, L. Ambient ozone and influenza transmissibility in Hong Kong. Eur. Respir. J. 2018, 51, 1800369. [CrossRef] [PubMed]

88. Chennakesavulu, K.; Reddy, G.R. The effect of latitude and PM2.5 on spreading of SARS-CoV-2 in tropical and temperate zone countries. Environ Pollut 2020, 266, 115176. [CrossRef]

89. Gauderman, W.J.; Avol, E.; Gilliland, F.; Vora, H.; Thomas, D.; Berhane, K.; McConnell, R.; Kuenzli, N.; Lurmann, F.; Rappaport, E.; et al. The Effect of Air Pollution on Lung Development from 10 to 18 Years of Age. N. Engl. J. Med. 2004, 351, 1057-1067. [CrossRef] [PubMed]

90. Tian, Y.; Liu, H.; Wu, Y.; Si, Y.; Song, J.; Cao, Y.; Li, M.; Wu, Y.; Wang, X.; Chen, L.; et al. Association between ambient fine particulate pollution and hospital admissions for cause specific cardiovascular disease: Time series study in 184 major Chinese cities. BMJ 2019, 367, 16572. [CrossRef]

91. Takagi, H.; Kuno, T.; Yokoyama, Y.; Ueyama, H.; Matsushiro, T.; Hari, Y.; Ando, T. Higher Temperature, Pressure, and Ultraviolet Are Associated With Less COVID-19 Prevalence: Meta-Regression of Japanese Prefectural Data. Asia Pac. J. Public Health 2020, 38, 520-522. [CrossRef]

92. Tosepu, R.; Gunawan, J.; Effendy, D.S.; Ahmad, O.A.I.; Lestari, H.; Bahar, H.; Asfian, P. Correlation between weather and Covid-19 pandemic in Jakarta, Indonesia. Sci. Total Environ. 2020, 725, 138436. [CrossRef]

93. Zhu, L.; Liu, X.; Huang, H.; Avellan-Llaguno, R.D.; Lazo, M.M.L.; Gaggero, A.; Soto-Rifo, R.; Patino, L.; Valencia-Avellan, M.; Diringer, B.; et al. Meteorological impact on the COVID-19 pandemic: A study across eight severely affected regions in South America. Sci. Total Environ. 2020, 744, 140881. [CrossRef]

94. Raman, R.; Patel, K.J.; Ranjan, K. COVID-19: Unmasking Emerging SARS-CoV-2 Variants, Vaccines and Therapeutic Strategies. Biomolecules 2021, 11, 993. [CrossRef] [PubMed]

95. Wu, F.; Zhao, S.; Yu, B.; Chen, Y.M.; Wang, W.; Song, Z.G.; Hu, Y.; Tao, Z.W.; Tian, J.H.; Pei, Y.Y.; et al. A new coronavirus associated with human respiratory disease in China. Nature 2020, 579, 265-269. [CrossRef]

96. Korber, B.; Fischer, W.M.; Gnanakaran, S.; Yoon, H.; Theiler, J.; Abfalterer, W.; Hengartner, N.; Giorgi, E.E.; Bhattacharya, T.; Foley, B.; et al. Tracking Changes in SARS-CoV-2 Spike: Evidence that D614G Increases Infectivity of the COVID-19 Virus. Cell 2020, 182, 812-827.e9. [CrossRef] [PubMed]

97. Rochelle, P.; Walensky, M.; Henry, T.; Walke, M.; Anthony, S.; Fauci, M. SARS-CoV-2 Variants of Concern in the United StatesChallenges and Opportunities. JAMA. 2021, 325. [CrossRef]

98. Tao, K.; Tzou, P.L.; Nouhin, J.; Gupta, R.K.; de Oliveira, T.; Kosakovsky Pond, S.L.; Fera, D.; Shafer, R.W. The biological and clinical significance of emerging SARS-CoV-2 variants. Nat. Rev. Genet. 2021, 22, 757-773. [CrossRef]

99. Mwenda, M.; Saasa, N.; Sinyange, N.; Busby, G.; Chipimo, P.J.; Hendry, J.; Kapona, O.; Samuel Yingst, D.; Jonas, Z.; Hines, M.; et al. Detection of B.1.351 SARS-CoV-2 Variant Strain-Zambia, December 2020. MMWR Morb. Mortal. Wkly. Rep. 2021, 70, 280-282. [CrossRef] 
100. Horby, P.; Huntley, C.; Davies, N.; Edmunds, J.; Ferguson, N.; Medley, G.; Semple, C. NERVTAG_note_on_B.1.1.7_severity_for _SAGE_77_1_. Available online: https://assets.publishing.service.gov.uk/government/uploads/system/uploads/attachment_ data/file/961037/NERVTAG_note_on_B.1.1.7_severity_for_SAGE_77__1_.pdf (accessed on 25 November 2021).

101. Romano, C.M.; Felix, A.C.; Paula, A.V.; Jesus, J.G.; Andrade, P.S.; Candido, D.; Oliveira, F.M.; Ribeiro, A.C.; Silva, F.C.D.; Inemami, M.; et al. SARS-CoV-2 reinfection caused by the P.1 lineage in Araraquara city, Sao Paulo State, Brazil. Rev. Inst. Med. Trop. Sao Paulo 2021, 63, e36. [CrossRef]

102. Volz, E.; Mishra, S.; Chand, M.; Barrett, J.C.; Johnson, R.; Geidelberg, L.; Hinsley, W.R.; Laydon, D.J.; Dabrera, G.; O’Toole, A.; et al. Assessing transmissibility of SARS-CoV-2 lineage B.1.1.7 in England. Nature 2021, 593, 266-269. [CrossRef]

103. Faria, N.R.; Mellan, T.A.; Whittaker, C.; Claro, I.M.; Candido, D.D.S.; Mishra, S.; Crispim, M.A.E.; Sales, F.C.; Hawryluk, I.; McCrone, J.T;; et al. Genomics and epidemiology of a novel SARS-CoV-2 lineage in Manaus, Brazil. medRxiv 2021. [CrossRef]

104. Hamza, I.A.; Bibby, K. Critical issues in application of molecular methods to environmental virology. J. Virol. Methods 2019, 266, 11-24. [CrossRef]

105. Haramoto, E.; Kitajima, M.; Hata, A.; Torrey, J.R.; Masago, Y.; Sano, D.; Katayama, H. A review on recent progress in the detection methods and prevalence of human enteric viruses in water. Water Res. 2018, 135, 168-186. [CrossRef] [PubMed]

106. La Rosa, G.; Fratini, M.; della Libera, S.; Iaconelli, M.; Muscillo, M. Emerging and potentially emerging viruses in water environments. Ann. Ist. Super Sanita 2012, 48, 397-406. [CrossRef]

107. Moreira, N.A.; Bondelind, M. Safe drinking water and waterborne outbreaks. J. Water Health 2017, 15, 83-96. [CrossRef] [PubMed]

108. Rusiñol, M.; Gironés, R. Summary of Excreted and Waterborne Viruses. 2018. Available online: https://www.waterpathogens. org/book/summary-of-excreted-and-waterborne-viruses (accessed on 25 November 2021).

109. Cotruvo, J. 2017 WHO Guidelines for Drinking Water Quality: First Addendum to the Fourth Edition. J. Am. Water Work. Assoc. 2017, 109, 44-51. [CrossRef]

110. Carducci, A.; Federigi, I.; Liu, D.; Thompson, J.R.; Verani, M. Making Waves: Coronavirus detection, presence and persistence in the water environment: State of the art and knowledge needs for public health. Water Res 2020, 179, 115907. [CrossRef] [PubMed]

111. Duan, S.M.; Zhao, X.S.; Wen, R.F.; Huang, J.J.; Pi, G.H.; Zhang, S.X.; Han, J.; Bi, S.L.; Ruan, L.; Dong, X.P.; et al. Stability of SARS coronavirus in human specimens and environment and its sensitivity to heating and UV irradiation. Biomed. Environ. Sci. 2003, 16, 246-255.

112. Wang, X.W.; Li, J.S.; Jin, M.; Zhen, B.; Kong, Q.X.; Song, N.; Xiao, W.J.; Yin, J.; Wei, W.; Wang, G.J.; et al. Study on the resistance of severe acute respiratory syndrome-associated coronavirus. J. Virol. Methods 2005, 126, 171-177. [CrossRef] [PubMed]

113. Wurtzer, S.; Marechal, V.; Mouchel, J.-M.; Moulin, L. Time course quantitative detection of SARS-CoV-2 in Parisian wastewaters correlates with COVID-19 confirmed cases. MedRxiv 2020. [CrossRef]

114. Calvet, G.; Aguiar, R.; Melo, A.; Sampaio, S.; de Filippis, I.; Fabri, A.; Araujo, E.; Sequeira, P.; Mendonça, M.; Oliveira, L.; et al. Detection and sequencing of Zika virus from amniotic fluid of fetuses with microcephaly in Brazil: A case study. Lancet Infect. Dis. 2016, 6, 653-660. [CrossRef]

115. Guery, B.; Poissy, J.; Mansouf, L.; Séjourné, C.; Ettahar, N.; Lemaire, X.; Vuotto, F.; Goffard, A.; Behillil, S.; Enouf, V.; et al. Clinical features and viral diagnosis of two cases of infection with Middle East Respiratory Syndrome coronavirus: A report of nosocomial transmission. Lancet 2013, 381, 2265-2272. [CrossRef]

116. Zhao, J.-Y.; Yan, J.-Y.; Qu, J.-M. Interpretations of “Diagnosis and Treatment Protocol for Novel Coronavirus Pneumonia (Trial Version 7)". Chin. Med. J. 2020, 133, 1. [CrossRef]

117. Pan, F.; Ye, T.; Sun, P.; Gui, S.; Liang, B.; Li, L.; Zheng, D.; Wang, J.; Hesketh, R.; Yang, L.; et al. Time Course of Lung Changes On Chest CT During Recovery From 2019 Novel Coronavirus (COVID-19) Pneumonia. Radiology 2020, 295, 200370. [CrossRef]

118. Bouguezzi, A. COVID-19: Special Precautions in Dentistry. Open Access J. Biomed. Sci. 2020, 2. [CrossRef]

119. Fennelly, K.P. Particle sizes of infectious aerosols: Implications for infection control. Lancet Respir. Med. 2020, 8, 914-924. [CrossRef]

120. Siegel, J.D.; Rhinehart, E.; Jackson, M.; Chiarello, L.; Health Care Infection Control Practices Advisory Committee. 2007 Guideline for Isolation Precautions: Preventing Transmission of Infectious Agents in Health Care Settings. Am. J. Infect. Control 2007, 35, S65-S164. [CrossRef]

121. Dutra, F. Airborne Contagion and Air Hygiene: An Ecological Study of Droplet Infections. Am. J. Clin. Pathol. 1955, 25, 1301. [CrossRef]

122. Fabian, P.; McDevitt, J.; DeHaan, W.; Fung, R.; Cowling, B.; Chan, K.-H.; Leung, G.; Milton, D. Influenza Virus in Human Exhaled Breath: An Observational Study. PLoS ONE 2008, 3, e2691. [CrossRef] [PubMed]

123. Gralton, J.; Tovey, E.; McLaws, M.L.; Rawlinson, W. The role of particle size in aerosolised pathogen transmission: A review. J. Infect. 2011, 62, 1-13. [CrossRef] [PubMed]

124. Kenyon, T.; Valway, S.; Ihle, W.; Onorato, I.; Castro, K. Transmission of Multidrug-Resistant Mycobacterium tuberculosis during a Long Airplane Flight. N. Engl. J. Med. 1996, 334, 933-938. [CrossRef]

125. Macintyre, C.; Carnie, J.; Randall, M. Risk of transmission of tuberculosis among inmates of an Australian prison. Epidemiol. Infect. 2000, 123, 445-450. [CrossRef]

126. Mandalakas, A.; Kirchner, H.L.; Lombard, C.; Walzl, G.; Grewal, H.; Gie, R.; Hesseling, A. Well-quantified tuberculosis exposure is a reliable surrogate measure of tuberculosis infection. Int. J. Tuberc. Lung Dis. 2012, 16, 1033-1039. [CrossRef] [PubMed] 
127. Biryukov, J.; Boydston, J.A.; Dunning, R.A.; Yeager, J.J.; Wood, S.; Reese, A.L.; Ferris, A.; Miller, D.; Weaver, W.; Zeitouni, N.E.; et al. Increasing Temperature and Relative Humidity Accelerates Inactivation of SARS-CoV-2 on Surfaces. mSphere 2020, 5, e00441-20. [CrossRef]

128. Kormuth, K.; Lin, K.; Prussin Ii, A.; Vejerano, E.; Tiwari, A.; Cox, S.; Myerburg, M.; Lakdawala, S.; Marr, L. Influenza Virus Infectivity Is Retained in Aerosols and Droplets Independent of Relative Humidity. J. Infect. Dis. 2018, 218, 739-747. [CrossRef] 